\title{
MARINE MANAGEMENT AND THE SITING OF ELECTRICAL GENERATING STATIONS ON TROPICAL SHORELINES
}

\author{
by \\ STEPHEN L. COLES ${ }^{1}$ )
}

\begin{abstract}
Expanding utilization of electricity by developing tropical nations will produce increasing amounts of waste heat that will, in most cases, be disposed into natural water systems. Such disposal represents a serious potential marine management problem for nations which intensively utilize the nearshore marine environment in their subsistence economy. This communication reviews the marine environmental effects resulting from thermal disposal at three generating stations on the Island of Oahu, Hawaii and compares these with results of similar studies made elsewhere in the tropics and subtropics. Conclusions are drawn from these studies concerning desirable environmental features to be considered for thermal outfalls in tropical areas, and some environmental consequences of alternative methods of cooling water treatment are discussed.
\end{abstract}

\section{INTRODUCTION}

Thermal effluents produced as a by-product of conventional steam turbine electrical generation exert a pervasive influence on organisms adjacent to marine thermal outfalls. Extreme damage to benthic organisms has often resulted from thermal discharge into shallow nearshore areas in the tropics and subtropics (ROESSLER \& ZIEMAN 1969; JONES \& RANDALL 1973; KOLEHMAINEN et al 1974; JOKIEL \& COLES 1974), where ambient water temperatures are closer to upper thermal limits of resident organisms than in the case for temperate regions. Various technologies such as cooling towers and cooling ponds are available for removing waste heat directly to the atmosphere that do not impart thermal loading to natural water systems. However, these are generally expensive in terms of capital costs and land usage, and are generally less energy efficient than the once-through cooling process now in general, use. In tropical island-nations which have high ratios of shoreline to land areas, nearshore marine environments are especially likely to be the principal waste heat recipients. Development and utilization of electricity is increasing rapidly in many tropical nations and will continue to do so wherever economic development is a major governmental objective

1) Environmental department, Hawaiian electric company. Inc. P.O. Box 2750, Honolulu, Hawai 96803, U.S.A. 


\section{STEPHEN L. COLES}

Throughout the tropics the marine nearshore environment is intensively utilized in the subsistence economy of the human population. Inexpensive, readily-obtainable protein from the sea provides both food and medium of economic exchange for those who fish and farm the highly-productive, shallow areas. Therefore, for human and economic considerations alone, it is important to provide sufficient safeguards that these multiple uses can continue when electrical generating facilities are to be located along tropical shorelines. However, in establishing these standards, capricious requirements should be avoided that would unnecessarily increase the cost of electrical production and needlessly inhibit desirable economic development.

Temperature effects on marine organisms have been thoroughly studied under laboratory conditions, and general references on tolerance limits are available (KInNe 1970; BUSH et al 1974; GibBOns \& SHARITZ 1974; MERRIMAN \& THORPE 1976). However, most earlier studies were of temperate organisms. Much of the information on thermal tolerances of tropical marine organisms and on the community effects of thermal disposal in the tropics has only recently been developed. (JOHANNES 1975; JOHANNES \& BETZER 1975; ZIEMAN \& FERGUSON WOOD 1975).

For the past five years the Hawaiian Electric Company (HECO) has monitored the marine environmental effects of thermal effluent disposal from three generating stations on the Island of Oahu. This information will be summarized and compared with results from similar studies made elsewhere in the tropics and subtropics. Before making these comparisons, however, it would be informative to establish how rates of electrical generation on Oahu compare with other tropical regions. This information will help to provide a perspective of how well the HECO environmental information may apply to other areas, and where electricity-associated environmental problems may be expected in the future.

\section{ENERGY CONSUMPTION COMPARISONS}

The Island of Oahu, otherwise known as the City and County of Honolulu, is the principal population center of the Hawaiian Islands, with a 1975 population of 704,000. Both population and total power consumption have been increasing exponentially since 1900 . While population number has doubled in twenty- to twenty-five-year periods, electrical consumption up to 1970 doubled every six to eight years. This resulted in exponential increases in per capita electrical consumption between 1940 and 1972.

The 1973 total and per capita electrical consumptions of Oahu are compared with sixteen selected tropical or subtropical regions (Fig. 1), and 


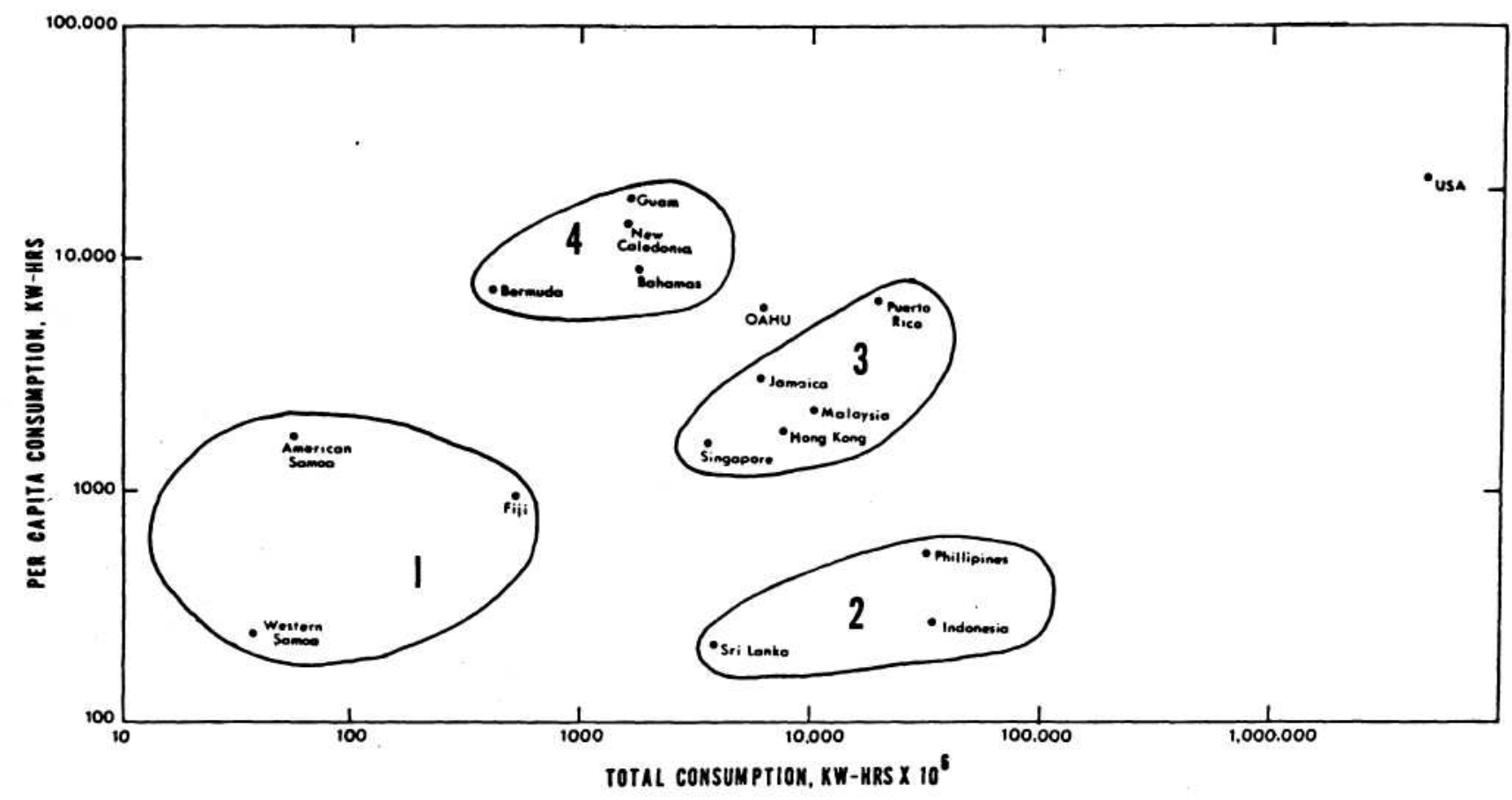

Figure 1. Per capita versus total electrical consumption (log scales) of sixteen selected tropical and subtropical regions and of the U.S.A. in 1973. 


\section{STEPHEN L. COLES}

with the Unites States as a whole (DEPARTMENT OF ECONOMIC AND SOCIAL AFFAIRS STATISTICAL OfFICE , UnITED NATIONS 1974). Surprisingly, in view of the rapid per capita consumption increases that have occurred on Oahu, its 1973 per capita electrical consumption was less than one third that of the United States, and was exceeded by the per capita consumptions of Bermuda, the Bahamas, Puerto Rico, New Caledonia and Guam. Oahu's economy is based principally on tourism and military expenditures. Electrical consumption is therefore principally by residential and business buildings, rather than by heavy industry which would drastically increase the per capita consumption value.

The areas selected for comparison with Oahu can be clustered into four groups on the basis of electrical consumption and population characteristics: Group 1 - Small total populations, low population densities and small per capita consumptions. Group 2 - Large total populations producing large total consumptions, but small per capita consumptions. Group 3 - Countries with high population densities and intermediate per capita consumptions. Group 4 - Small total population and low population density, but high per capita consumption. Most of group 3 and 4 countries have relatively high degrees of industrialization and at least moderately high standards of living. It is apparent that the nationstates of groups 2 and 3, with their large populations, present the greatest potential thermal waste disposal management problem, given continued increases in electrical and population growth. Growth in total consumption for these nations averaged 4.4\% annually between 1970 and 1973, which would give a doubling time of sixteen years. Growth for Indonesia, which is fortunate to be one of the few oil-rich nations of the world, was $12.5 \%$ annually for the 19701973 period. At this rate of increase, it would require only about sixty years for Indonesia's total electricity consumption to equal that of the U.S.A. in 1973, some 5 trillion kilowatt hours.

It would be misleading to rely too much on these types of projections since rates of increase in power consumption are quite variable and have, in fact, declined substantially since 1973. However, it is apparent that electricity production by methods producing a waste heat by-product is likely to continue to increase at least to the end of this century, and that increasing amounts of waste heat will be disposed into the marine environment. The data indicate that present electrical consumption on Oahu ranks somewhere in the middle of the per capita extremes for tropical and subtropical regions. Marine environmental conditions resulting from electrical production on Oahu may therefore be considered representative of a subtropical island with a Honolulu-Size population. 
MARINE MANAGEMENT AND THE SITING OF ELECTRICAL

\section{MARINE ENVIRONMENTAL EFFECTS - OAHU}

The Hawaiian Electric Company operates three generating stations on the Island of Oahu (Fig. 2). Two of these dispose thermal effluent into estuaries: one at Honolulu Harbor and the other into the East Loch of Pearl Harbor. The third station is on an open coastline at Kahe Point on leeward Oahu. Present facilities at Honolulu, the oldest and smallest of these stations, began operating in 1930 and presently has a rated capacity of 180 megawatts (mw). The Pearl Harbor station presently has about double this generating capacity and has operated since 1938. The Kahe station began operation in 1963 and is now the principal baseload generator for Oahu, with a present capacity of about $500 \mathrm{mw}$. Operating characteristics and physical features of the marine environment at these stations are summarized (Table 1).

Investigations conducted since 1972 have revealed only very limited impact on resident marine communities by thermal effluent from either the Honolulu or Pearl Harbor stations. (MCCAIN \& COLES 1973; MCCAIN 1974; ENVIRONMENTAL CONSUltants et al. 1974, 1976; MCCAIN et al 1975). The receiving waters of these harbors receive a variety of industrial pollutants and heavy sedimentation, and the marine communities are generally composed of hardy eurytopic species. Although some localized depression of phytoplankton standing crop, chlorophyll concentration and productivity has been measured in the immediate vicinity of the outfall at both stations, detrimental effects have not been recorded beyond this trophic level. Although some entrainment damage to macrozooplankton and larval fish can be assumed, the standing populations of these in outfall areas have not been found to be adversely affected. Likewise, adult fish populations have not been found to be negatively affected by thermal discharge. At least one positive influence has been noted. The Honolulu station discharges effluent heated approximately $5^{\circ} \mathrm{C}$ into a basin adjacent to an entrance to Honolulu Harbor. The walls of the station intake and discharge basins are the only area within the harbor supporting a population of reef corals, although substantial hard surface for coral settlement is available elsewhere in the harbor. Apparently increased water movement provided by the generating station has promoted coral settlement in this section of the harbor.

The only other major community alteration directly attributable to either station has been found at the Pearl Harbor site (MCCAIN 1975). Recirculation of effluent is restricted by a sheet piling extending from the shoreline outfall. A study of the benthic community settling on fouling panels along the intake and discharge sides of the sheet piling delineated a 
TABLE I. Operating characteristics and environmental impacts of six tropical electrical generating stations

\begin{tabular}{|c|c|c|c|c|c|c|c|c|}
\hline $\begin{array}{l}\text { Station, } \\
\text { Location }\end{array}$ & $\begin{array}{l}\text { Coastal } \\
\text { Type }\end{array}$ & \begin{tabular}{|r} 
Benthic \\
Environment
\end{tabular} & $\begin{array}{l}\text { Av. Annual } \\
\text { Ambient } \\
\text { Temp. } \\
\text { Range, }{ }^{\circ} \mathrm{C}\end{array}$ & \begin{tabular}{|l} 
Generating \\
Capacity, \\
MW (Date)
\end{tabular} & $\begin{array}{l}\text { Temp. } \\
\text { Rice }{ }^{\circ} \mathrm{C}\end{array}$ & $\begin{array}{l}\text { Benthic } \\
\text { Area } \\
\text { Damaged, } \\
\text { ha }\end{array}$ & \begin{tabular}{|c|} 
Lethal \\
Threshold \\
Temp. \\
${ }^{\circ} \mathrm{C}$
\end{tabular} & $\begin{array}{l}\text { Other } \\
\text { Community } \\
\text { Effects at Outfall }\end{array}$ \\
\hline $\begin{array}{l}\text { Honolulu Harbor, } \\
\text { Oahu }\end{array}$ & \begin{tabular}{|l} 
Estuarine, \\
Drowned Valley
\end{tabular} & $\begin{array}{l}\text { Soft Sediment, } \\
\text { limited coral }\end{array}$ & $21-28$ & \begin{tabular}{|l}
$180(1976)$ \\
\end{tabular} & $4.5-5.5$ & None & - & $\begin{array}{l}\text { Increased zooplankton } \\
\text { \& fish at discharge }\end{array}$ \\
\hline $\begin{array}{l}\text { Pearl Harbor, } \\
\text { Oahu }\end{array}$ & \begin{tabular}{|l} 
Estuarine, \\
Drowned Valley
\end{tabular} & $\begin{array}{l}\text { Soft Sediment, } \\
\text { filter feeders }\end{array}$ & $21-29$ & 430 (1976) & $5.5-7.0$ & None & - & $\begin{array}{l}\text { Sublethal } \\
\text { community } \\
\text { alteration at ca } 32^{\circ} \mathrm{C}\end{array}$ \\
\hline $\begin{array}{l}\text { Kane Point, } \\
\text { Oahu }\end{array}$ & $\begin{array}{l}\text { Open, Coral } \\
\text { Reef }\end{array}$ & $\begin{array}{l}\text { Reef coral, } \\
\text { sand }\end{array}$ & $23-27$ & 500 (1976) & $5.0-6.0$ & 1.4 & $31-32$ & $\begin{array}{l}\text { Sand deposition, algal } \\
\text { growth, fish } \\
\text { attraction }\end{array}$ \\
\hline $\begin{array}{l}\text { Turkey Point, } \\
\text { Biscayne Bay, } \\
\text { Fla. }\end{array}$ & \begin{tabular}{|l} 
Estuarine, \\
Barrier Laggon
\end{tabular} & $\begin{array}{l}\text { Mangrove, } \\
\text { Thalassia macro- } \\
\text { algae on lime- } \\
\text { stone }\end{array}$ & $17-31$ & 864 (1970) & 5.0 & 118 & $33-34$ & $\begin{array}{l}\text { Avoidance by motile fauna } \\
\text { inhibition and death of } \\
\text { sessile, Blue-green algal } \\
\text { mats }\end{array}$ \\
\hline $\begin{array}{l}\text { Guayanilla Bay, } \\
\text { Puerto Rico }\end{array}$ & $\begin{array}{l}\text { Estuarine, } \\
\text { Semi-enclosed }\end{array}$ & $\begin{array}{l}\text { Mangrove, } \\
\text { Thalassia mud } \\
\text { bottom }\end{array}$ & $25-31$ & $\begin{array}{l}310(1971) \\
1100(1972)\end{array}$ & 10.0 & $\begin{array}{l}\text { not deter- } \\
\text { mined }\end{array}$ & $35-36$ & $\begin{array}{l}95 \% \text { zooplankton mortality } \\
\text { Avoidance of } 34^{\circ} \mathrm{C} \text { by mo- } \\
\text { tile fauna, Blue-green mats }\end{array}$ \\
\hline $\begin{array}{l}\text { Tanguisson Pt. } \\
\text { Guam }\end{array}$ & $\begin{array}{l}\text { Open, Coral } \\
\text { Reef }\end{array}$ & $\begin{array}{l}\text { Barren reef Hat, } \\
\text { Reef margin live } \\
\text { coral }\end{array}$ & $26-29$ & $6(1970)$ & $6.5-8.0$ & 1.0 & $32-33$ & $\begin{array}{l}\text { Reduced no. algae species, } \\
\text { Blue-green mat formation, } \\
\text { Fish avoidance }\end{array}$ \\
\hline
\end{tabular}


MARINE MANAGEMENT AND THE SITING OF ELECTRICAL

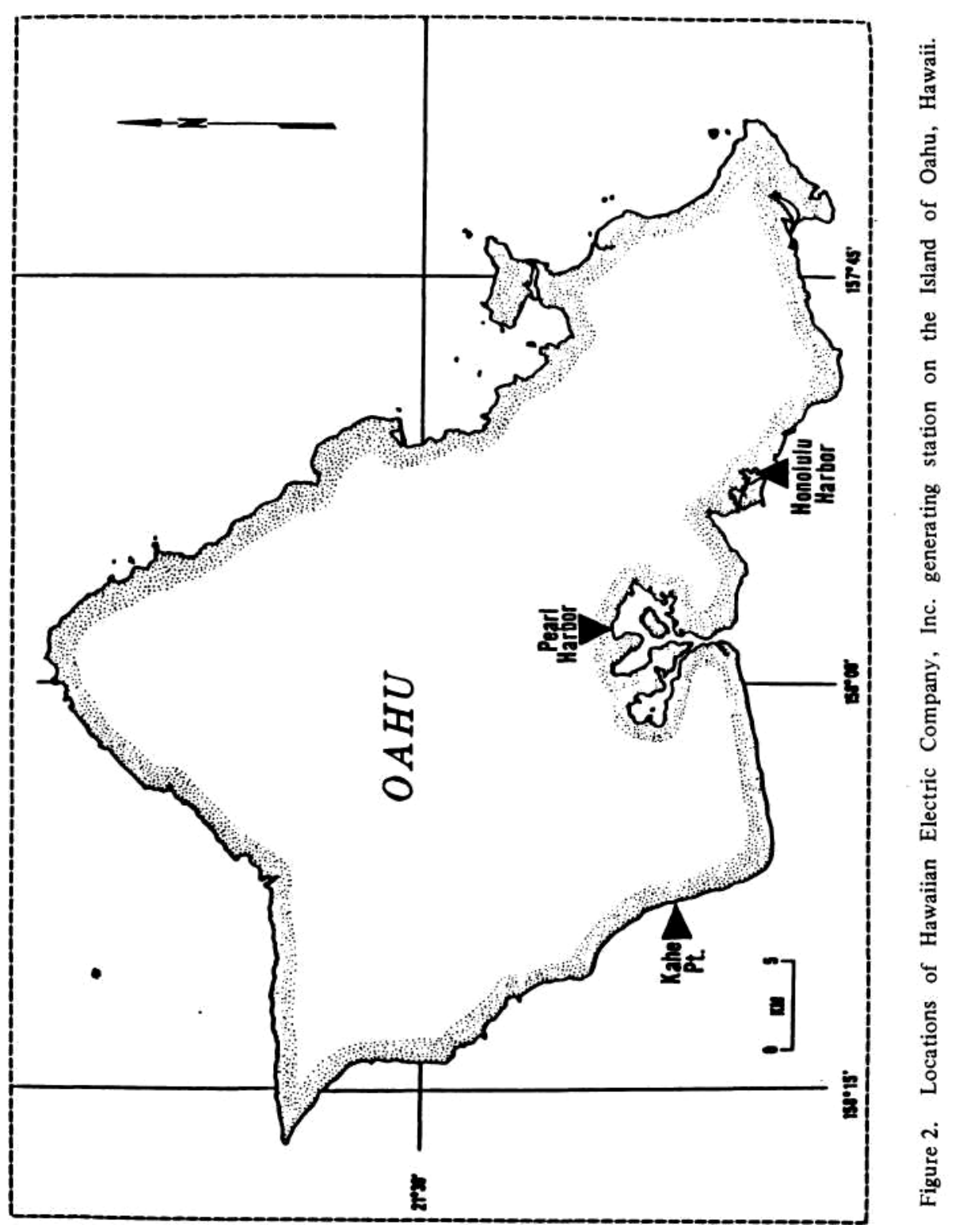




\section{STEPHEN L. COLES}

community of reduced standing crop and species composition corresponding to the $+3^{\circ} \mathrm{C}$ isotherm, or an annual temperature maximum of approximately $32^{\circ} \mathrm{C}$.

The estuarine conditions and marine communities of Honolulu and Pearl Harbor contrast strikingly with the marine environment at the Kahe Point station site. Here the shoreline is completely open to the sea and is composed of white sand beaches or emerged beachrock. Sublittoral depths rapidly increase with distance from shore and support a rich coral reef with one of the highest coverages of live coral to be found in Oahu waters. Longshore tidal currents and offshore prevailing tradewinds normally promote the rapid seaward dispersion and dissipation of thermal effluent.

Many of these physical characteristics associated with an open leeward coastline would indicate this area to be a potentially ideal site for the disposal of cooling water discharge. Ironically, this is the only Oahu station site where substantial environmental problems have occurred. (JOKIEL \& COLES 1974). Notably, none were evident before 1971 when the station was operating at less than $300 \mathrm{mw}$. Detrimental effects were observed after 1971 only when oceanic ambient temperatures reached their $27^{\circ} \mathrm{C}$ annual maximum. During these warm months it was apparent that reef coral was being damaged or killed by discharge from the shoreline outfall. Water temperatures in this area ranged up to $32^{\circ} \mathrm{C}$ in zones of dead coral, while sublethal reduction of coral zooxanthellar pigmentation occurred where temperatures were 29 to $30^{\circ} \mathrm{C}$. During the following year the station's operating capacity was increased by about one third, and the area of dead and damaged coral nearly doubled, increasing from 0.4 hectare to 0.7 hectare. The benthos of the affected area became dominated by a thermophilic red algal mat, and large populations of herbivorous fish have been noted to be attracted to the area (MCCAIN \& PECK 1973).

Conditions in the area stabilized during 1973 and 1974, with little additional impact noted (COLES 1975). However, Kahe generating capacity was again increased in early 1975 by some $40 \%$ to nearly $500 \mathrm{mw}$, and an additional shoreline outfall began releasing effluent at this time. Substantial coral mortality again resulted and the total affected area again doubled, to approximately 1.4 hectares at present. However, most of this additional benthic damage was due to deposition of sand that had been entrained in cooling water and then dispersed by the station's discharge. The benthic damage and tendency of effluent to recirculate at Kahe have required the present construction of an offshore outfall. This will extend $260 \mathrm{~m}$ offshore to about $8 \mathrm{~m}$ depth, and will cost approximately nine million dollars to construct. 
In contrast to the benthic damage described, investigations at Kahe have revealed little or no impact to other segments of the marine community (COles \& MCCAIN 1973; COles \& FuKUdA 1975) and have indicated benthic impact to be localized to the immediate outfall area. Although substantial volumes of plankton are entrained in the cooling water, zooplankton and larval fish populations sampled at the Kahe outfall cannot be distinguished from those sampled at the intake or in control areas. (ENVIRONMENTAL CONSUltants InC. 1974). Substantial numbers of juvenile and adult fish are attracted by either currents or elevated temperatures directly to the outfall and the area is very popular with recreational fishermen. Also, sharks tend to congregate in the thermal plume during winter and spring when ambient water temperatures are minimal. Despite this apparent attraction of fish to the Kahe outfall, fish move freely into and out of the area and show no overt negative influences attributable to contact with the thermal plume.

\section{COMPARATIVE STUDIES}

Studies made at thermal outfalls elsewhere in the tropics and subtropics may be compared with these Oahu studies in order to anticipate the extent of environmental damage that might result from power station development in a tropical area. Three such studies which encompass a variety of environments and ambient temperature regimes have been conducted in Florida, Puerto Rico and Guam (Table 1).

By far the greatest damage among these occurred at the outfall for the Turkey Point Station which originally discharged into South Biscayne Bay, Florida. (ROESSLER \& ZIEMAN 1969; ZIEMAN \& FERGUSON WOOD 1975). This area is an estuarine barrier lagoon only one to two meters deep, bordered on its outside by a sand cay. Circulation within the lagoon is minimal, and the annual ambient temperature range is very large, reaching up to $33^{\circ} \mathrm{C}$. Consequently, discharge temperatures reached as high as $39.5^{\circ} \mathrm{C}$ during the second year of operation, and produced a massive shorterm kill of fish and invertebrates over at least 228 hectares. The zone of persistent mortality to turtle grass and benthic macroalgae extended over 50 hectares and coincided with the $+4^{\circ}$ to $+5^{\circ}$ benthic isotherm, while about 70 hectares contained damaged macroalgae and coincided with the $+3^{\circ}$ isotherm.

The second station compared is located at Guayanilla Bay on the south coast of Puerto Rico. (Kolehmainen et al 1974.) Despite its large volume output and its very high operating temperature increase of $+10^{\circ} \mathrm{C}$, benthic damage from this station was apparently much less than reported at Biscayne 


\section{STEPHEN L. COLES}

Bay. primarily because of the much greater vertical relief at Guayanilla Bay, and the fact that here thermal effluent is less restricted from reaching the open ocean. Also, evidence indicates higher optimum and lethal threshold temperatures for the resident biota than apply for Biscayne Bay. However, substantial mortality occurred at this station in turtle grass beds and macroalgae communities where temperatures exceeded $35^{\circ} \mathrm{C}$ and sublethal effects occurred above $33^{\circ} \mathrm{C}$. Fish diversity was reduced in the discharge, and $95 \%$ of the zooplankton entrained by the plant were killed. Although mangrove growth itself was not adversely affected by thermal effluent, many sessile invertebrates normally living on mangrove prop roots are excluded by temperatures above $34^{\circ} \mathrm{C}$.

The Guam Tanguisson Point power station (JONES \& RANDALL 1973) is located on a leeward open coastline similar to that at Kahe Point. However, the reef at Tanguisson is more typically tropical, with coral growth restricted to the margin of a shallow reef flat which supports macroalgae. Shortly after the station began operating, the number of macroalgae species in the path of the discharge decreased by more than two-thirds. As also occurred in Biscayne Bay and in Puerto Rico, blue-green algal mats came to dominate the area. All fish left the outfall area, but a few species returned when chlorination within the station was discontinued. However, the most prominent environmental disturbance occurred at the reef margin and reef front, where thermal effluent stratified at the surface was entrained and mixed downward by surf action. Corals died in the manner described for Kahe Point, and the kill area eventually extended to about 1.0 hectare. Coralline algae were also killed within this area. Considering that the generating capacity of this station was only $26 \mathrm{mw}$, a kill area of 1 hectare is a very large impact. This resulted primarily because effluent mixed by wave action tended to be carried parallel to the reef margin in a zig-zag pattern, moving with the variation in prevailing offshore currents.

\section{DISCUSSION AND CONCLUSIONS}

These comparative studies were principally concerned with relatively short-term thermal effects on epibenthic habitat formers. Limited information is available (REEVE 1970) concerning the effects of generating station entrainment of plankton from tropical waters, or what ultimate importance plankton entrainment damage may pose to the marine ecosystem as a whole. However, ZIEMAN \& FERGUSON WOOD (1975) have proposed that plankton entrainment and destruction is potentially relatively unimportant compared to benthic considerations for the following reasons: 
1. Limited studies suggest that dominant zooplankters have higher thermal tolerances than dominant benthic habitat formers.

2. Phytoplankton is relatively unimportant in food webs of tropical estuaries.

3. Turnover rates of plankton are much greater than those of benthic organisms; consequently substantial amounts of plankton can be destroyed without altering the major portion of the marine community biomass or long-term energy flow.

An additional consideration is that plankton are exposed to stress by entrainment for only seconds to minutes, whereas stress is a continuous condition for benthic organisms exposed to thermal effluent. Similarly, fish and other motile organisms can leave an area when physical conditions become intolerable.

Studies at the Oahu generating stations indicate that the zooplankton and fish communities are not measurably affected by entrainment or effluent discharge, and that entrainment-related changes, such as small reductions in phytoplankton productivity, do not prohibit the maintenance of a balance and viable biotic community. In some cases, e.g. fish growth and the zooplankton community composition at the Honolulu Harbor outfall, discharge effects have been interpreted as beneficial. (Mc CAIN \& COLES 1973; MCCAIN et al. 1975). These studies indicate that tropical plankton and nekton are not seriously affected by thermal effluent unless discharge temperatures are very high $\left(37-40^{\circ} \mathrm{C}\right)$; such has occurred at the Florida and Puerto Rico stations. However, damage to benthic organisms is apparent well below these extreme temperatures.

A general conclusion from these and related laboratory studies is that epibenthic habitat formers such as macroalgae, reef corals and coralline algae are also the most thermally sensitive organisms to be found in tropical waters. Therefore, measures which adequately protect benthic organisms subject to thermal-stress should adequately protect the major portion of the remaining marine community. This is convenient from the standpoint of evaluating thermal damage since these benthic indicator organisms are sessile, large enough to be seen, and results of thermal damage are quite obvious.

The Biscayne Bay study points out that shallow estuaries of the barrier island-lagoon type should be strictly avoided when siting generating stations. In fact, high vertical sublittoral relief should be considered as necessary a physical feature for a potential thermal discharge site as rapid water circulation and prevailing offshore winds. Because of their high vertical relief, estuaries of the drowned river valley type such as Honolulu and Pearl Harbors may in some cases be acceptable potential sites for stations up to 


\section{STEPHEN L. COLES}

$400 \mathrm{mw}$, depending on the composition of the resident biota. For continents and continental islands, the estuarine areas at the mouths of large rivers may offer the best potential power station sites for both environmental and engineering considerations. However, in these cases attention must be paid to the possibility of thermal barriers to fish movement and to the potential effects of land runoff. Storm conditions can produce sufficient low density fresh water to overlay the surface-stratified thermal plume, preventing the dissipation of its heat into the atmosphere, and bringing heated discharge into contact with benthic communities that would be otherwise unaffected.

Although common sense would suggest that thermal outfalls would best be sited on open coastlines with unrestricted water circulation, the Kahe and Tanguisson Point situations indicate that such location by itself does not guarantee the prevention of serious marine disturbances in tropical areas, especially where coral reefs occur. In fact, benthic communities resident along these open coastlines are likely to be among the most sensitive to thermal stress since they are normally exposed and adapted to relatively cooler oceanic water. Furthermore, these stenothermal organisms generally are at their highest diversity and abundance in shallow depths where temperatures of the surface-stratified thermal effluent are highest. When such areas are utilized for power station siting, expensive protection measures, such as deep ocean outfalls, probably will be required.

As important a consideration as the siting of a station is the temperature rise that its operations impose. It has long been recognized that tropical marine organisms live much closer to their upper thermal limits than do their temperate counterparts (MAYER 1914); however, recent studies indicate that upper thermal limits of tropical organisms are not fixed in an absolute sense, but rather are closely tied to the temperature history of the organism's geographic area. (COLES et al. 1976; KOLEHMAINEN et al. unpublished). For example, considerable variation was found among lethal threshold temperatures pertaining to the six case studies presented here, but in all cases mortality resulted in temperatures of 3 to $5^{\circ} \mathrm{C}$ above ambient maxima, and elevation of 2 to $3^{\circ}$ produced sublethal effects. Consequently, designed condenser temperature rises of power stations operated in the tropics should not exceed $5^{\circ} \mathrm{C}$, especially during warmer months. Here the interests of the power engineer and the environmentalist are fortunately in agreement, since a low cooling water discharge temperature results in increased plant operating efficiency and in fuel savings.

Although fossil fuels now provide the energy for most electrical generation in the tropics, nuclear-powered generation will probably become the common method in areas where new demands exceed 1,000 megawatts. 
Nuclear generating stations arc planned to be operating for the cities of Manila, Jakarta and Bangkok in the early 1980's. Because of lack of stack heat loss and the necessity of a lower operating combustion temperature, the heat that must be conducted by cooling water from a nuclear-fueled plant per kilowatt generated is substantially greater than for fossil fuel. Consequently, discharge temperatures are usually higher and problems associated with disposal of thermal effluent into receiving waters are magnified.

Alternative methods of cooling water treatment are available that would prevent disposal of thermal effluent directly into receiving water. The most practicable of these methods are wet draft cooling towers, or cooling ponds which keep the cooling water in a closed system, and the pumping of effluent into the ground by means of injection wells. Each of these methods, although superficially attractive, has serious drawbacks. Closed systems are considerably less fuel efficient than direct once-through cooling, no small consideration during a time of increasing fuel costs. Moreover, cooling towers present special marine environmental problems. (MINER \& WARRICK 1974). Although the cooling tower keeps heated discharge within a closed cycle, the evaporation process continuously produces a continuous brine residue called blowdown which is greatly enriched in heavy metals. This blowdown is generally more toxic to marine organisms than the thermal effluent from which it is indirectly derived. Restriction of the blowdown from the marine environment requires large land areas for evaporation and precipitation, as do cooling ponds, and land is a scarce commodity in highlypopulated tropical regions.

Injection well disposal may prove to be a practicable means of heat removal in areas with porous rock substrata. However, sometimes this method only appears to complicate and aggravate the problems. In one such situation on the Island of Hawaii, a generating station has been proposed to be located about $150 \mathrm{~m}$ from the coastline and draw its cooling water from ground water sources. Studies indicate that only moderate cooling of effluent will occur as it percolates through the rock, and that the still warm water eventually will reach the sublittoral zone from underneath (HOLMES \& NARVER, Inc. 1976). Consequently, a station generating only about 100 mw has been projected to have the potential of thermally damaging a benthic area of about 45 hectares by this means of disposal, about two orders of magnitude greater than damage that might be expected from a point source shoreline discharge.

In conclusion, it is expected that the once-through method of cooling water discharge will continue to be the most economically feasible and energy efficient method of waste heat removal for power stations located in 


\section{STEPHEN L. COLES}

tropical marine areas. If proper precautions are taken in station siting and operation, this method of disposal will produce only limited, tolerable disturbance to the marine environment. The major problem involved in using the ocean as a waste heat recipient lies in getting effluent far enough from the shoreline to cause minimal damage to shallow water benthic communities. It is hoped that the dispassionate and informed criticism of concerned marine ecologists will provide valuable input toward achieving this purpose.

\section{REFERENCES}

BUSH, R. M.; E. H. WELCH and B. W. MAR 1974. Potential effects of thermal discharges on aquatic systems. Environ. Sci. Tech. 8:561 - 568.

COLES, S. L. 1975. A comparison of effects of elevated temperature versus temperature fluctuations on reef corals at Kahe Point, Oahu. Pac. Sci. 29: 15-18.

COLES, S. L. and J. C. MCCAIN 1973. Effects of the Kahe Generating station on the nearshore environment: a report of the 1973 monitoring program. Hawaiian Electric Co., Inc., Honolulu. 199 pp.

COLES, S. L. and D.T. FUKUDA 1975. Reef coral and algal communities of the Kahe nearshore region of Oahu, Hawaii. Report to Hawaiian Electric Company, Inc., Honolulu. 89 pp.

COLES, S. L.; P. L. JOK1KL, and C. R. LEWIS 1976. Thermal tolerance in tropical versus subtropical Pacific reef corals. Pac. Sci. 30:159-166.

DEPARTMENT OF ECONOMIC AND SOCIAL AFFAIRS STATISTICAL OFFICE, UNITED NATIONS 1975. Statistical yearbook 1974. 877 pp.

ENVIRONMENTAL CONSULTANTS, INC. 1974. Plankton studies at Kahe, Oahu. Report to Hawaiian Electric Co., Inc., Honolulu. 110 pp.

ENVIRONMENTAL CONSULTANTS, INC. AND HAWAIIAN ELECTRIC CO., INC. 1974. The marine biological impact of the Honolulu Generating Station: A summary of the 1974 investigations. Report to Hawaiian Electric Co., Inc., Honolulu. 102 pp.

GIBBONS, J. W. and R. R. SHAKITZ 1974. Thermal Ecology. Proc. AEC CONF-730505. U.S. Dept. Commerce, Springfield, Va. 670 pp.

HOLMES \& NARVER, INC. 1976. Environmental impact analysis for a proposed West Hawaii Generating Station, Island of Hawaii, Hawaii. Report to Hawaiian Electric Co., Inc., Honolulu, vol. 1. 329 pp.

JOHANNES, R. E. 1975. Pollution and degradation of coral reef communities, p. 13-51. In: Tropical marine pollution (E. J. FERGUSON WOOD and R. E. JOHANNES eds.) Elsevier, Amsterdam. 192 pp.

JOHANNES, R. E. and S. B. BKTZER 1975. Introduction: Marine communities respond differently to pollution in the tropics than at higher latitudes, p. 1 -12. In: Tropical Marine Pollution (E. J. FERGUSON WOOD and E. J. JOHANNES eds.) Elsevier, Amsterdam. 192 pp.

JOK1FTL, P. L. and S. L. COLES 1974. Effects of heated effluent on hermatypic corals at Kahe Point, Oahu. Pac. Sci. 28: i 18.

70 


\section{MARINE MANAGEMENT AND THE SITING OF ELECTRICAL}

JONES, R. S. and R. H. RANDALL 1973. A study of biological impact caused by natural and maninduced changes on a tropical reef. Univ. Guam Marine 1Mb. Tech. Rept. 7:1-184.

KINNE, O. 1970. Temperature, p. 321-573. In: Marine Ecology, vol. 1, chap. 3 (O. KINNE ed.). WilleyInterscience, N.Y. 681 pp.

KOLEHMA1NEN, S.; T. MORGAN and R. CASTRO 1974. Mangrove root communities in a thermally altered area in Guayanilla Bay, Puerto Rico. Proc. AEC CONF. 730505. p.371-390.

MAYER, A. G. 1914. The effects of temperature on tropical marine animals. Carnegie Inst. Wash. Publ. 183:3-24.

MCCAIN, J. C. 1974. Environmental survey, Waiau Generating Station. Report to Hawaiian Electric Co., Inc., Honolulu. 186 pp.

1975. Fouling community changes induced by the thermal discharge of a Hawaiian power plant. Environ. Pollut. 9:65-83.

MCCAIN, J. C. and J. M. PECK, JR. 1973. The effects of a Hawaiian power plant on the distribution and abundance of reef fishes. Univ. Hawaii Sea Grant Rept. AR-73-03. Honolulu. 16 pp.

MCCAIN, J. C. and S. L. COLES 1973. The marine biological impact of the Honolulu Generating Station: A summary of the 1973 investigations. Report to Hawaiian Electric Co., Inc., Honolulu. 137 pp.

MCCAIN, J. C; S. L. COLES and J. M. PECK, JR. 1975. The marine biological impact of the Honolulu Generating Station. Sea Grant Tech. Rept. UNIHI-SEA GRANT-TR-76-01. 50 pp.

MERR1MAN, D. and L. M. THORPE 1976. Introduction, p. 1-23. In: The Connecticut River Ecological Study. The impact of a nuclear power plant. (D. MERR1MAN and L. M. THORPE eds.).Am. Fish. Soc. Monogr. No. 1. 251 pp.

MINNER, R. M. and J. W. WARR1CK 1975. Environmental effects of cooling system alternatives at inland and coastal sites. Nuclear Technol. 25:

REEVE, M. R. 1970. Seasonal changes in the zooplankton of south Biscayne Bay and some problems of assessing the effects on the zooplankton of natural and artificial thermal and other fluctuations. Bull. Mar. Sci. 20:894-921.

ROESSLER, M. A. and J. C. ZlEM AN 1969. The effects of thermal additions on the biota of southern Biscayne Bay, Florida. Proc. Gulf and Caribbean Fish. Inst., 22nd sess. p. 136-145.

ZIEMAN, J. C. and E. J. FERGUSON WOOD 1975. Effects of thermal pollution on tropical-type estuaries, with emphasis on Biscayne Bay, Florida, p. 75-98./H: Tropical marine pollution (E. J. FERGUSON WOOD and R. E. JOHANNES eds.). Elsevier, Amsterdam. 192 pp. 